\title{
Christian worship: A matter of justice
}

\section{Matsobane J. Manala ${ }^{1}$}

\begin{abstract}
This article highlights the value of Christian worship in the lives of Christians. It argues that worship should sensitise Christians towards justice and the practice thereof and it highlights my personal observations of the religious actions of some churches, contrasting their lack of concern for justice with God's positive concern for justice. The article defines Christian worship and explores-and establishes as indissoluble-the relationship between Christian worship and justice. The article also explores the meaning of the concept of "justice" and concludes that the link between worship of God and acts of justice is similarly indissoluble. Expanding on this link, and exploring the relationship between Christian worship and justice, the article further establishes that the practice of justice is a constituent part of authentic Christian worship. The implications of justice-focused Christian worship are found to be quite meaningful: helping church members to accept and respect the humanity of all people, especially the weak, the vulnerable and the voiceless; changing situations of dire need; bringing about serious and genuine transformation in the lives of both the rich and the poor; and affirming the value of active Christian presence, community and vocation. In conclusion, I recommend that the faith community actively identify with the poor, with those infected with or affected by HIVIAIDS, with foreigners and with other marginalised people, and that they do so in prophetic, priestly and kingly presence.
\end{abstract}

Keywords: Christian worship, justice, relationship, central prophetic message, marginalisation, love, respect, the poor, the HIV and AIDS infected, foreigners, identify.

\section{Introduction}

Christian worship has been the core activity of the Christian church since its inception; it is also at the heart of the missio Dei. Missio Dei should here be understood as referring to what the American missiologist James A. Scherer says was Luther's understanding of the concept (Engelsviken 2003:481):

For Luther, mission is always pre-eminently the work of the triune God-missio Dei-and its goal and outcome is the coming of the kingdom of God. Luther sees the church, along with God's word and every baptized believer, as crucial divine instruments for mission. ... It is always God's own mission that dominates Luther's thought, and the coming of the kingdom of God represents its final culmination.

Missio Dei is indeed the work of God, of which Christian worship forms the very heart. Many churches hold mandatory weekly gatherings at which they have fellowship around the Word. Some denominations also hold additional quarterly gatherings at which they have fellowship around both the Word

1 Prof. Matsobane J. Manala is an Associate Professor in the Department of Practical and Systematic Theology at the University of South Africa. He teaches Practical Theology and serves as discipline leader. He can be contacted at manalmj@unisa.ac.za. 
and the sacraments. Bickel (2005) writes about sacraments from a Calvinistic perspective:

Historically, Calvinists have recognized that Jesus instituted two sacraments: baptism and the Lord's Supper. During the Reformation of the Church, John Calvin defined a sacrament as "an outward sign by which the Lord seals on our consciences the promises of his good will toward us in order to sustain the weakness of our faith; and we in turn attest our piety toward him in the presence of the Lord and of his angels and before men" (Institutes of the Christian Religion, Book 4, Chapter 14). In other words, a sacrament does two things:

1. A sacrament sustains faith in the gospel by confirming its promises.

2. A sacrament declares that the one who receives it is a true worshipper of God.

The gatherings may be spirit filled and dynamic, and might include enthusiastic singing and dancing, as well as fervent prayer. Such gatherings represent the communion of Christians - individually and collectivelywith God and with fellow Christians. Christian worship is of primary importance in that it is an opportunity for the appointed encounter between God and human beings. A further important value of Christian worship is that it brings people together on a regular basis for a common purpose. It is thus a meeting of the loving God with God's redeemed people. It should be understood and experienced both as an occasion of God's coming to God's people and of God's people meeting their loving, caring and saving Godfor praise and adoration, and to have their focus shifted from self-centredness and self-interest to God, to other-centredness, and to selflessness. Chapman (2001:274), affirming this demand for selflessness in worship writes, citing Percy Dearmer:

The best hymns of Christendom are as free as the Bible from the self-centred sentimentalism, the weakness and unreality which mark inferior productions. The great hymns, indeed, of all ages abound in the conviction that duty lies at the heart of the Christian life- a double duty to God and to our neighbour; and such hymns, like the Prayer Book, are for all sorts and conditions of men.

Altruism is the required attitude of God's worshippers. The focus should be on God and on others as required by God's justice.

\subsection{Observing the reality of religious actions of some Christian churches}

When one interacts with and observes some churches in their practice and articulation of worship, however, it becomes clear that they regard it as intended exclusively for their own communal interests. Such a view of Christian worship tends to influence congregations to be inward looking and 
to neglect Christ's commandment of love towards God and towards others. The church that is inward-looking in its character is nothing but a self-worshipping community - which is, without doubt, idolatrous. White (1987:2) raises a painful situation that is inimical to Christian worship: "Those marginalised by society are likely to be marginalised in worship ... Those whose full human worth is likely to be denied outside of worship are almost certain to be similarly marginalised within worship." Women and children have, for many years, been at the receiving end of this marginalisation. The seriousness of this marginalisation is expressed vigorously by former United States President Jimmy Carter (2009), who went so far as to leave his denomination as a result of gender discrimination. He writes:

I have been a practising Christian all my life and a deacon and Bible teacher for many years. My faith is a source of strength and comfort to me, as religious beliefs are to hundreds of millions of people around the world. So my decision to sever my ties with the Southern Baptist Convention, after six decades, was painful and difficult. It was, however, an unavoidable decision when the convention's leaders, quoting a few carefully selected Bible verses and claiming that Eve was created second to Adam and was responsible for original sin, ordained that women must be "subservient" to their husbands and prohibited from serving as deacons, pastors or chaplains in the military service.

This view that women are somehow inferior to men is not restricted to one religion or belief: women are prevented from playing a full and equal role in many faiths. Nor, tragically, does its influence stop at the walls of the church, mosque, synagogue or temple. This discrimination, unjustifiably attributed to a Higher Authority, has provided a reason, or excuse, for the deprivation of women's equal rights across the world for centuries.

Such conduct can only render Christian worship inauthentic. Wolterstorff (1991:9) highlights some differing approaches to Christian worship that rob it of its authenticity: firstly, being verbal about worship but without seriously and practically living out what is professed in and about worship; secondly, being too dogmatic and conventional about who should be leading the worship services (the question of ordination or non-ordination); and, thirdly, excluding women from leadership in worship. For those espousing the first approach, Christian worship is, in reality, untruthful and does not honour God. Regarding the second and third approaches, it appears that, as a result of insistence on clericalism and sexism, justice is not being served.

It is my observation that some South African churches appear to believe that placating God with exotic liturgical actions is sufficient and pleasing to him. This attitude persists, despite the pain, oppression, marginalisation and 
deprivation that the voiceless people of this country suffer and have to endure, even with apartheid defeated. Even those churches that helped break apartheid through their eloquent and prophetic words and conduct seem to have abandoned this divine prophetic imperative. Guroian (1997:373) blames this attitude on the secularisation of the West: "The deterioration of Christian worship and disciplines of prayer has deprived the churches of necessary tools of discernment and creativity to build ethics from within the ecclesial body itself. Ordinary Christians very often adopt secular moralities without knowing the difference between these moralities and Christian ethics."

\subsection{God's concern for justice and the practice thereof}

God is pleased, however, only when worshippers are concerned with and practise justice. Being concerned with and practising justice is indeed in accordance with the true marks of the church, as Guroian (1997:374) points out, citing the report of the Tantur Ecumenical Institute consultation of November 1994:

The traditional marks of the church —oneness, catholicity, apostolicity and holiness - are all to be expressed in the moral life of its members. Oneness calls for deepening love and communion; catholicity involves being welcoming to the rich diversity within community; apostolicity suggests reaching out to neighbours in sharing truth received from Jesus Christ; and straightforward, unself-conscious goodness is an essential dimension of holiness. These are central expressions of what it means to be the body of Christ.

Concern for justice and the practice thereof are thus the ontological dimension of the church and essential requirements for Christian worship. This is emphasised by Wolterstorff (1991:10), citing the words of the Old Testament prophet Amos about God's dislike of, and disgust at, the Israelites' worship that neglected justice:

I hate, I despise your feasts, and I take no delight in your solemn assemblies. Even though you offer me your burnt offering and cereal offerings, I will not accept them, and the peace offerings of your fatted beasts I will not look upon. Take away from me the noise of your songs; to the melody of your harps I will not listen. But let justice roll down like waters and righteousness like an ever flowing stream (Amos 5:21-24).

Given the significance of worship, one could assert that (a) regular congregational engagement in Christian worship occasions is one of the defining characteristics of the Christian church; $(b)$ embracement of the Old and New Testament Scriptures as normative for life and work is another defining characteristic of Christian worship; and (c) justice is central to Christian conduct, both inside and outside of Christian worship 
(Wolterstorff 1991:6). These three defining characteristics produce true worship only when they are all the concern of the worshipping community.

In this article, I will describe two important concepts briefly: "Christian worship" and the requisite "justice". Thereafter, I will reflect on the relationship between liturgy and justice and, from this, the implications for Christian worship will emerge. This should make it possible to reach meaningful conclusions and make recommendations that may help the church return to authentic Christian worship.

\section{Understanding Christian worship and its nature}

It is difficult to define "worship" in such a way that every aspect of its make-up is covered sufficiently well. It is important, though, to note that worship is undoubtedly a central religious activity of humankind in reverential honour of its deity. Robinson (2000:25) gives a brief but broad definition that is interesting to note: "worship is an [human] activity in response to God's Lordship".

Kibiku (2006:103) is quite apt in his definition of "worship":

[W]orship means reverence offered a divine being or supernatural power; an act of expressing such reverence. [It is] a form of religious practice with its creed and ritual. According to Graham Kendrick, worship is worth - worship expresses the value placed on someone or something. The true quality and depth of our love for God will to a very great degree be evidenced by the quality and depth of our worship. When we value somebody, we do things to demonstrate that love; we put our thanks, appreciation and adoration into words, we give thanks, gifts and show that we care in practical ways. Indeed how often do we hear the complaint, "you say you love me, but you never show it?" Talk is cheap, but actions do speak louder than words and are a test of whether our words are genuine.

Central to such understanding of worship are the following two important points: (a) worship is the act of expressing reverence to a divine being or supernatural power; and $(b)$ worship is an expression of acknowledgement of the value placed on the one being worshipped. Kibiku (2006:103) further writes:

Further definition of worship is praise, adoration, confession, proclamation and reverence of God. This is celebration of worthiness. The Greek word for worship is "proskyrieo" which means "to kiss" (the hand), to come forward, prostrating or bowing. Bowing or kissing is an attitude of submission and obedience and involves giving ourselves unreservedly to God. True worship springs from deep within the heart and is expressed in our relationship with God and also with others. It should actually affect everything that we do in Church life and outside it. We worship God and work out that 
worship by loving one another. If we are critical or negative with others, we're not really expressing our worship to God. So a good definition of worship is: Loving God in the presence of his people and loving God's people in the presence of God.

Highlighted in the preceding definition are three important activities emanating from the attitude displayed by the worshipper towards the worshipped, as well as towards his or her fellow worshippers and, indeed, towards all humanity: (a) celebrating God's worthiness; $(b)$ displaying an attitude of submission and obedience to God; and $(c)$ the act of loving God and God's people.

Christian worship is, therefore, an activity of the worshipping person (or persons) - one that takes place as part of an encounter and relationship with God and with other worshipping persons. It is thus a covenantal dialogical act that takes place as part of an encounter between a human being and his or her God, an encounter that may include other human beings. Burns (2009:375), citing Hovda, writes: "[W] hat is most important about public worship is that we gather the sisters and brothers together for a festival, a celebration of the reign of God (not yet terribly evident in daily life nor in the institutions of society), that helps us feel so good about ourselves, so important, so dignified, so precious, so free, so much at one." It is, however, not just about celebrating the reign of God and feeling good; it is about acting in divinely inspired, good and helpful ways. Chapman (2001:272) states about Dearmer: "For Dearmer, worship didn't exist in another world - it wasn't about escape, about making us feel nice and fuzzy or warm and content like sipping from a glass of whisky in a comfortable armchair. Rather, it was about giving the best from this world, the best of human creativity, back to God.'

Worship entails an act of God, who is the initiator, and a human act in humble and obedient response. Worship is meant to be a lived-out reality and not just confessed or sung about (Labberton 2007:20). "Since worship is more than texts, every gathered, communal Christian assembly, in whatever ecclesial tradition, can be said to enact some sort of liturgy, scripted or unscripted, whatever its relation to particular sets of texts for prayer and particular works of art." (Burns 2009:373). Liturgy is said to mean "work of the people" or public service. It is clear therefore that worship must inspire and activate people towards performance of works of justice. It has to inspire service to God and to others. Burns (2009:373), explicating the concept of liturgy, adds: "Hence, it is often closely allied in contemporary liturgical theology with the notion of participation; 'full, conscious and active participation' being widely regarded as principal key to the renewal of worship."

The focal point of Christian worship is and remains the glorious God and his love made concrete in the birth, life, death, resurrection and ascension of his Son, Jesus Christ (Manala 2009:13). What the above statement of faith 
means is that only God is to be worshipped (Wheeler 2003:17) and obeyed. Murdock (2006:3) points to the centrality of God in the Reformed tradition, saying: "Central to this tradition is the affirmation of the majesty, holiness, and providence of God who creates, sustains, rules, and redeems the world in the freedom of sovereign righteousness and love". Christian worship is indeed expected to express worshippers' gratitude - in a way that pleases God-for God's self-giving to them in the form of Christ. As White (1987) points out: "An important dimension of worship is its divine context."

One could indeed justifiably say that Christian worship is an imperative for all Christian believers. Kelly (1998:262) writes: "[L]iturgy is the Christian community's consciousness of grace." Conscious of the grace of God and its value in their redemption individually and corporately, the faith community finds itself obligated to act in gratitude towards God, God's people and God's world. Giving what can rightly be considered compelling reasons for worship, Crowe (2007:465) says: "I offer two reasons that a theist might provide for the claim that worship is obligatory: (1) a divine command and (2) the demands of justice with respect to God's redemption of humanity". Accordingly, observance of God's will and commands, as well as the demands of justice, are the main drivers of Christian worship. Justice, without doubt, is an essential component of Christian worship. Aquinas is cited as having said: "[R]eligion is a moral (rather than a specifically theological) virtue connected to justice. ... Thus, religion is a virtue of rendering God his due." "Aquinas makes it clear that religion includes worship, both as an attitude and as a set of patterned activities" (Crowe 2007:470). Having pointed out that Christian worship is an imperative for all Christian believers, it must be understood as an imperative that is achievable because, as Purcell (1997:144) points out: "In fact, [t]he sanctification of man [sic] consists of his [sic] being enabled to glorify God."

Worship can be said to be bifocal because, while it focuses on God and God's glory as "work of the people", it also focuses on people as "work for the people" (Burns 2009:374). Purcell (1997:145) attests to this truth when he says: "What we wish to maintain is that liturgy manifests an essential structure as 'for-the-Other', whether this other be the divine majesty or the human other." This expresses, succinctly, the link between worship and justice. Worship is, in this regard, both the glorification of God and service to God's people. The Christian memory of the central salvific events forms the source and motivation for justice. The following meaningful words of Gurioan (1997:372) point to Christ's redemption, his life, death and resurrection, as well as his second glorious coming, as the source and motivation for Christian liberty and virtuous living:

Christian liberty and virtue arise out of the church's memory of the central salvific events in the life, death and resurrection of Jesus Christ. We Christians even engage in the rather odd liturgical activity 
of remembering the future. Sunday is not the seventh day of the secular week; it is the eschatological eighth day or the first day of the New Creation. So on that day, under the symbol of the eucharist, the church not only remembers the past, it also remembers the future; indeed the prayer of anamnesis in the earliest Christian liturgies and Orthodox liturgies to this day call to memory not only Christ's crucifixion, resurrection and ascension but also "his awesome and glorious second coming".

The memory of these central events - which includes the future dimension - has to be transformative and metanoic. Such transformation cannot do otherwise than lead the Christian worshipper to expected holiness and, therefore, to the doing of justice. Gurioan (1997:376) demonstrates how the lex orandi is linked to the lex credendi and the lex bene operandi, saying: "[E]ach informs, influences and deepens the other two in the ground of our beseeching and our prayerful praise of God." Weaver (2002:3) also affirms this when he rightly states: "Authentic Christian worship bears fruit in Christian living." He proceeds: "Worship begins with God, but its end and goal is the transformation of human life so that the image of the God who is worshipped in Jesus Christ may find expression in the life and conduct and relationships of the worshipper. Lowell Mason's hymn reminds us that 'Love so amazing, so divine, demands my soul, my life, my all.' " (Weaver 2002:3). The life of the worshipper is thus bound to be reflective of God's loving grace. Chapman (2001:272) writes about the views of Dearmer on liturgy: "The liturgy was there to express God's justice: it was about performing our roles as citizens of the new Kingdom." It is, therefore, important here, in an attempt to understand this significant virtue connected to our Christian worship, to reflect briefly on justice.

\section{Understanding justice}

Justice is a difficult concept to comprehensively fathom and define. Rich in meaning and significance, the term demands that an attempt be made towards obtaining further clarity as to its meaning. There are at least two ways of understanding "justice", namely as a punitive or corrective act of God against a disobedient people, and as an obedient act(s) of God's people following God's demand for justice. These two meanings are discussed by Berguist (1993:54-61) in light of two opposing interpretations of Amos 5:21-24 by the two opposing schools of thought.

Lissitzyn (1932:632), finding it difficult to define the term "justice", writes: "The word 'justice' is itself rather difficult to define. According to Alpian, "justice" is the constant wish of rendering to everyone his [sic] right." " Indeed, the pursuit of justice is in many countries loud and clear, continuous and unstoppable. While I understand and agree that justice is constant, I believe that justice cannot and should not be understood simply as 
a wish but also as a desirable real action in the "rendering to everyone... [their] right". It is the equitable availing of life-giving amenities to all human beings. I believe it is for this reason that former South African President, Nelson Mandela, is cited as stating justice in more concrete terms when he said: "Overcoming poverty is not a gesture of charity. It is an act of justice. It is the protection of a fundamental human right, the right to dignity and a decent life. While poverty persists, there is no freedom [my emphasis]".

It is understandable, therefore, that the International Conference on Globalisation for the Common Good (2005) defines "justice" as a core issue for life: "Justice is the heart of all creation. It is the profound feeling of oneness with all other beings in the universe. Today, it finds its most vital expression in social and economic fairness, concern for others and the vigorous defence of human rights." This is indeed what makes Christian worship genuine worship. It is reminiscent of the meaningful words of Dietrich Bonhoeffer, cited by Fuchs (1993:18), regarding the church: "The Church is only the Church when it is there for the other people." In the same vein, it can with justification be said that any display of self-centredness, aloofness and self-seeking on the part of the church and church worship disqualifies such a church and such worship. Only when it is concerned with, among other things, the plight of other people and when it is committed to addressing that plight in order to bring about shalom for those people is Christian worship genuine and proper. It was Jesus who raised this issue quite clearly in Matthew 25:31-46 when the King rewarded the righteous people because they had cared for the vulnerable and by so doing had cared for him. To the unrighteous, the King gave no reward but rather condemnation because they did not care for the weak and vulnerable and in so doing had neglected to care for him.

Justice can, therefore, rightly be viewed as the real measure of the success of Christian worship. The success of our worship is indeed inextricably linked to genuine concern for justice. The International Conference on Globalisation for the Common Good (2005), after affirming the "conviction that people everywhere prosper where justice and equity are honoured", states: "Globalisation for the common good is predicated on a global economy ... whose aim is generosity and the promotion of a just distribution of the world's goods, which are divine gifts."

Justice is, without doubt, one central demand of God placed on God's people. It is indeed the central prophetic message to God's people. Examples of prophetic sayings from the prophets Isaiah and Jeremiah with regard to God's demand for the practice of justice follow. Isaiah 56:1: "This is what the Lord says: 'Maintain justice and do what is right for my salvation is close at hand and my righteousness will soon be revealed." " In almost the same vein, the prophet Isaiah states: "Is not this the kind of fasting I have chosen: to loose the chains of injustice and untie the cords of 
the yoke, to set the oppressed free and break the yoke?" (Isa. 58:6). Caring for and seeing to the freeing and protection of the vulnerable are demanded of God's people. The prophet Jeremiah too is clear in articulating God's demand for justice. In Jeremiah 21:12, we read: "O house of David, this is what the Lord says: 'Administer justice every morning; rescue from the hand of his [or her] oppressor the one who has been robbed, or my wrath will break out and burn like fire because of the evil you have done-burn with no one to quench it." "How else will the oppressed experience the love and mercy of God if it is not through God's worshippers? The oppressed are defenceless people who have no one else to turn to when circumstances necessitate their search for refuge. Again, Jeremiah points to God's demand for justice when he says: "This is what the Lord says: Do what is just and right. Rescue from the hand of the oppressor the one who has been robbed. Do no wrong or violence to the alien, the fatherless or the widow and do not shed innocent blood in this place." (Jeremiah 22:3). The Scriptures quoted above make it clear that believers - specifically Christian believers - cannot afford to be mere confessors but must also care for those in life-denying circumstances. God places orphans, widows, the oppressed and foreigners (or aliens) in the path of Christian worshippers to challenge them towards true and active compassion. The worship of God is, or should be, indissolubly linked to acts of justice.

\section{The relationship between Christian worship and justice}

At the centre of, and serving as the identity-giving aspect of Christian worship, is justice. This means that Christian worship minus justice can never be genuine worship. Jesus Christ, who is the focus of Christian worship, taught and practised justice through and through. For example, he taught in the Sermon on the Mount: "Blessed are those who hunger and thirst for justice, for they shall be satisfied." (Matt. 5:6). He also said: "Blessed are those who are persecuted for the sake of justice, for theirs is the kingdom of heaven." (Matt. 5:10). Justice, according to the above assertions of Jesus, is as indispensable a component of Christian worship as Christian lifestyle. It is something for which to strive and to endure the harshest of persecutions. Wolterstorff (1991:6) writes in this regard: "In calling humanity to practice and struggle for justice, and in blessing those who do, Jesus was standing in continuity with the great prophetic tradition of the Old Testament". Justice is thus also a divine imperative of the God of the Old Testament. It is understood that, even today, God wants Christians to practise and strive for justiceespecially in one of their most sacred activities, namely worship. As Wolterstorff's title "Justice as a condition of authentic liturgy" (1991:6) proclaims, justice is actually a condition of authentic worship.

The question is: in what specific ways are the two related? Observing the conduct and reactions of people - those who concern themselves with 
social justice issues, those who concern themselves exclusively with the practice of liturgy, and those concerned with evangelism - as Wolterstorff (1991:7) does, one realises that there is tension, aloofness and suspicion between one and the other. The relationship, therefore, is not always easy to maintain. For Christians, however, this is not a matter of social justice or liturgy or evangelism. Christians are expected to follow a more holistic approach.

\section{Implications for Christian worship}

Justice is constitutive for Christian worship. Labberton (2007:170) sees the public witness of God's people as resting on whether Christians live out their identity. Justice is the core character of Christian worship. It sensitises Christian worship to focus outwards, to love, respect and help the poor and destitute people of God. Vorster (2007:80) says: "The biblical concept of justice as it is used in the Old and New Testament is a soteriological concept with direct cosmological implications." This statement clearly points to the demands placed on Christian worship in its relation to justice. Vorster (2007:80) also writes: "The justice that God gives should result in a life of justness between people (Amos 5:24). He who belongs to the covenant should behave in a way befitting it. The cosmological implication of God's justice is therefore that believers should seek and promote justice in inter-human relations". Justice, in this regard, implies that Christian worship (as an act of the redeemed people who are therefore new creatures in Christ and who are gathered before the just God) cannot do other than good, either in the moment of worship or outside the sphere of worship.

Justice promotes mutual love and respect, as well as total respect for the rights of others. It helps church members accept and respect the humanity of all people, especially the weak and voiceless. White (1987) writes about justice and its influence on worshippers: "Justice within the church's worshipping community ascribes full human worth to all members of the body of Christ." Christian worship brings different people together to worship God, but also to intensify their compassion towards the poor, widows, orphans and strangers.

Christian worship changes situations of dire need and brings about serious and genuine transformation in the lives of both the rich and the poor. Labberton (2007:169) points out that justice-embedded worship promotes mutuality. He writes: "To know those who live in Christ for the sake of others while facing overwhelming circumstances all around them has been transformative to me." This transformation extends beyond self to society as a whole. In this regard, King (1988:91) writes: "Liturgy and sacraments do, in effect, flow from the deepest roots and wellsprings of life and experience. They celebrate life as a precious gift and a challenging task, even though it is sometimes beset with hurt and injustice. Christian rites are also intended to transform life, not only within us personally but in our society and world 
as well." The implication then, of justice-focused worship is that it brings about transformation from a life of confession to a life of life-giving, Spirit-inspired action working towards the expansion of God's kingdom for the realisation of God's shalom. The word "shalom" is here used to denote wholeness or completeness in terms of peace, well-being, safety and so forth, Preceptaustin (n.d.) states: "The root meaning of shalom is to be whole or sound and this leads to translations that speak of completeness, wholeness, well-being, welfare and peace. Shalom also includes the idea of vigour and vitality in all dimensions of life. In short, shalom speaks of holistic ("holy") health for our souls and spirits." The worshipping community is required to do justice in order for the poor and oppressed people to experience such glorious wholeness.

Gerkin (1991:91-164) discusses three important normative metaphors for pastoral work namely presence, community and vocation, which prove to be relevant in my discussion of the implications of striving for and practising God's justice. Christian presence, community and vocation are quite essential in our contemporary world, characterised as it is by poverty, the prevalence of HIV/AIDS infection and by xenophobic attacks. The justice-inspired Christian presence, community and vocation among the poor, among those infected with and affected by HIV/AIDS and among foreigners would indeed light up the lives of the marginalised and dejected, empower the powerless and give voice to the voiceless, suffering people of God. This is possible because, as Gerkin (1991:107) points out, these metaphors are not abstract references but refer to the concrete and practically meaningful availability of Christian worshippers in contexts of distress. A worshipping Christian community-one that is concerned with issues of justice - through its actions displays acceptance of the other in the same way each of its members accepts himself or herself. This is akin to what happens in the context of Ubuntu (Manala 2002), that is, mutual respect and acknowledgement and helping those in need for the survival of all.

The poor, along with foreigners and people living with HIV/AIDS, will understand and experience the real meaning of the good news of salvation and join in praising and magnifying God when they find themselves in the company of Christian worshippers who strive for and offer justice.

Sub-Saharan Africa, of which South Africa is a part, is noted for its HIV/AIDS prevalence. Writing in Divine Justice Human Justice, Dreyer (2002:86) states:

In this region alone, 3.8 million adults and children became infected with HIV during 2000, which brings the total number of people living in this region with HIV/AIDS to 25.3 million. This means that approximately $70 \%$ of people with HIV/AIDS live in Africa, south of the Sahara desert. More than $75 \%$ of the 21.8 million people who 
have died of AIDS since the beginning of the epidemic lived in sub-Saharan Africa.

This is a serious challenge for the peoples of sub-Saharan Africa-and South Africa is said to be among the worst affected countries within this cluster (Dreyer 2002:86). Christian theologians and worshippers are challenged to release the floods of justice, to display and enact unconditional acceptance, as well as any practical assistance that those infected and affected may need. Yet, Dreyer (2002:86) asserts that HIV/AIDS is one of the most neglected problems among theologians and South African religious communities. This view supports my own observation in respect of the attitude and conduct of many Christians within my denomination.

The Christian community, as a sensitive community, cannot be negligent in the context of the HIV/AIDS pandemic. Manala (2010:525) rightly asserts: "[T] he church can only be meaningfully helpful if it identifies with the vulnerable in a prophetic, priestly and kingly presence and action." According to Koopman (2008:253), the Christian community should protect the vulnerable and marginalised by "being advocates of human rights, rights that resist the violation of dignity and that help dignity to flourish by championing for values like equality, freedom, justice and equity". Calling such a stance the preferential option for the poor, "The practical implication of this preferential option for the poor is that, through its conscientisation efforts, it must seek to arouse and mobilise the poor and oppressed to a take firm stand against poverty, oppression and suffering and join the God of the Exodus and of Jesus the Christ (the liberator) to become instruments of their own liberation (Martey 1993:98)." The poor, the oppressed and the marginalised need this empowerment and the worshipping Christian community has the vocation to accomplish this in the spirit of justice.

The plight of foreigners is a further indictment on a worshipping Christian community that also worships people for being South African. Where is justice when foreigners suffer severe attacks? The xenophobic attacks of 11 May 2008 in Alexandra township, and the subsequent spread thereof to other provinces (see Zondi 2008; Landau 2010), is an ugly blight on a state that is supposedly democratic - one that has an entrenched human rights constitution and a Christian tradition, both of which demand the equal and humane treatment of people. Christian worshippers are called to pray for tolerance and peace, as well as to call strongly upon the xenophobic to repent and to teach them the altruistic love and embracement of the other that were displayed by our Lord Jesus Christ. Christian worshippers should actively campaign against xenophobia and make it their business to protect foreigners.

\section{Conclusion and recommendations}

This article has attempted to define Christian worship. Its definition of Christian worship can be summarised thus: (a) celebration of God's 
worthiness; $(b)$ displaying an attitude of submission and obedience to God; and (c) the act of loving God and God's people. These three basic truths about Christian worship have been found to be the very essence of Christian worship, worship that cannot be complete without God's justice.

The article has defined Christian worship and highlighted the value of Christian worship in the lives of Christians. It has argued that Christian worship should sensitise Christians towards justice and the practice thereof. It has also highlighted observations of the reality of Christian religious actions taking place in some churches, as well as God's concern for justice and the practice thereof. The article has explored the meaning of the concept "justice" and concluded that the worship of God is, or has to be, indissolubly linked to acts of justice. In exploring the relationship between Christian worship and justice, it was established that the practice of justice by the Christian worshipping community is constitutive to authentic Christian worship. The implications of justice-focused Christian worship were found to be quite meaningful: helping church members to accept and respect the humanity of all people, especially the weak and voiceless; changing situations of dire need; bringing about serious and genuine transformation in the lives of both the rich and the poor; and affirming the value of active Christian presence, community and vocation.

Observations of my own denomination, as well as a literature review, have however pointed to the deficiency in terms of the practice of justice. For instance, Dreyer (2001:86) rightly points out that: "HIV/AIDS is one of the most neglected problems amongst theologians and South African religious communities." Considering the three basic truths that constitute the essence of Christian worship, and the fact that authentic worship is one that engenders acts of justice, something drastic needs to be done for the worshipping community to bring to concretion its celebration of God's worthiness, the display of its submission and obedience to God, and its love of God and of God's people.

What must be done? The Christian community must identify with the poor, with those living with HIV/AIDS and with foreigners and other marginalised people in prophetic, priestly and kingly presence, that is, teaching and advocacy, serving them sacrificially, protecting them against oppression and campaigning for their rights. This is the measure of Christian justice. 


\section{References}

Berquist, J.L. 1993. Dangerous waters of justice and righteousness: Amos 5:18-27. Biblical Theology Bulletin: A Journal of Bible and Theology 23(2) May: 54-63.

Bickel, D.R. 2005. Seeing the forgiveness of God: The sacraments from John Calvin's perspective. http://dawningrealm.org/sacraments/calvin/ [accessed 20 Nov. 2012].

Buffel, O.A. 2010. Preferential option for the poor in the current context of poverty in South Africa: Doing liberation theology in the footsteps of Simon Maimela. Studia Historiae Ecclesiasticae 36(supp.), July:99-113.

Burns, S. 2009. Liturgy and justice. International Journal of Public Theology 3(3), May:371-389.

Carter, J. 2009. Losing my religion for equality. http://www.theage.com.au/opinion/losing-my-religion-for-equality-20090714-dk 0v.html?page $=-1$ [accessed 20 Nov. 2012].

Chapman, M.D. 2001. Percy Dearmer: Liturgy and justice Luke 8:22-35. Theology 104(820), July:271-276.

Crowe, B.D. 2007. Reasons for worship: A response to Bayne and Nagasawa. Religious Studies 43(4), December:465-474.

Dreyer, J.S. 2002. Justice for the oppressed: The HIV/AIDS challenge, in Divine justice - Human justice, edited by J.S. Dreyer and J.A. van der Ven. Pretoria: Research Institute for Theology and Religion, University of South Africa:85-112.

Engelsviken, T. 2003. Missio Dei: The understanding and misunderstanding of a theological concept in European churches and missiology. International Review of Mission 92(367), October:481-497.

Fuchs, O. 1993. God's people: Instruments of healing. Bern: P. Lang.

Gerkin, C.V. 1991. Prophetic pastoral practice: A Christian vision of life together. Nashville, Tenn.: Abingdon Press.

Guroian, V. 1997. Moral formation and Christian worship. Ecumenical Review 49(3), July:372-378.

International Conference on Globalisation for the Common Good. 2005. Africa and globalisation for the common good: The quest for justice and peace. http://www.religion-online.org/showarticle.asp?title=3091 [accessed 21 Nov. 2012].

Kelly, M. 1998. Towards a renewed liturgy. Furrow 49(5), May:259-269.

Kibiku, P.M. 2006. Christian worship in an African context. Berlin: Viademica.

Labberton, M. 2007. The dangerous act of worship: Living God's call to justice. Downers Grove, Ill.: InterVarsity Press.

Landau, L.B. 2010. Loving the alien? Citizenship, law, and the future in South Africa's demonic society. African Affairs 109(435), April:213-130.

King, J.N. 1988. Liturgy and life. Furrow 39(2), February:91-100. 
Koopman, N. 2008. Vulnerable church in a vulnerable world? Towards an ecclesiology of vulnerability. Journal of Reformed Theology 2(3), August:240-254.

Lissitzyn, O.J. 1932. The meaning of the term denial of justice in international law. American Journal of International Law 30(4), October:632-646.

Manala, M.J. 2002. Education for reconstruction: A post-apartheid response to the education crisis in South Africa. Hervormde Theological Studies 58(3), October:1032-1055.

Manala, M.J. 2009. Reformed worship in the Maranatha Reformed Church of Christ. Theology and the Church in South Africa 1(2), November:4-30.

Manala, M.J. 2010. "A better life for all": A reality or a pipe-dream? A black theology intervention in conditions of poor service delivery in the democratic South Africa. Scriptura 105(3), November:519-531.

Mandela, N. 2005. Speech given at the first campaign to make poverty history in London's Trafalgar Square on 03 February (Unpublished paper). http://www.makepovertyhistory.org/docs/mandelaspeech.doc [accessed 21 Nov. 2012].

Murdock, M.L. 2006. The transformational voice of the kingdom of God. D.Min. mini thesis, Gordon-Conwell Theological Seminary, South Hamilton, Mass.

Preceptaustin. http://www.preceptaustin.org/shalom___definition.htm.

Purcell, M. 1997. Liturgy: Divine and human service. Heythrop Journal 38(2), April:144-164.

Robinson, E.B. 2000. How shall we now worship? Applying the regulative principle. WRS Journal 7(1), February:24-35.

Vorster, J.M. 2007. Christian attitude in the South African liberal democracy. Potchefstroom: Potchefstroom Theological Publications.

Weaver, J.D. 2002. Presbyterian worship: A guide for clergy. Louisville, Ky.: Geneva Press.

Wheeler, G.J. 2003. Visual art, the artist and worship in the Reformed tradition: A theological study. D.Phil. thesis, Australian Catholic University, Victoria.

White, J.F. 1987. Moving Christian worship toward social justice. http://www.religion-online.org/showarticle.asp?title $=351$ [accessed 20 Nov. 2012].

Wolterstorff, N. 1991. Justice as a condition of authentic liturgy. Theology Today 48(1), April:6-21.

Zondi, S. 2008. Xenophobic attacks: Towards an understanding of violence against African immigrants in South Africa. Africa Insight 38(2), September:26-35. 